\title{
PDE9A wt Allele
}

National Cancer Institute

\section{Source}

National Cancer Institute. PDE9A wt Allele. NCI Thesaurus. Code C125490.

Human PDE9A wild-type allele is located in the vicinity of 21 q22.3 and is approximately

$122 \mathrm{~kb}$ in length. This allele, which encodes high affinity cGMP-specific 3',5'-cyclic

phosphodiesterase 9A protein, is involved in the metabolism of both cyclic GMP and cyclic

AMP. 